\title{
Korelasi antara sistem vulkanisasi dengan sifat mekanis dan sifat redaman vulkanisat karet butil tanpa pengisi
}

\section{Correlation of vulcanization system with mechanical and damping properties of unfilled butyl rubber vulcanizate}

\author{
Adi Cifriadi*, Asron Ferdian Falaah, Santi Puspitasari \\ Balai Penelitian Teknologi Karet, Pusat Penelitian Karet, Jalan Salak Nomor 1 Bogor 16128, Indonesia \\ *Penulis korespondensi. Telp. +62 $2518317819 / 8324047$ \\ E-mail: acip9748@gmail.com
}

Diterima: 6 Juni 2021

Direvisi: 28 Nopember 2021

Disetujui: 1 Desember 2021

\begin{abstract}
Generally, the damping properties of butyl rubber are influenced by the amount of crosslink, and type and amount of filler used. In this study, the butyl rubber was compounded without filler because the filler greatly altered the material properties.. The compound is prepared in a conventional, semi-efficient and efficient sulfur vulcanization system with various ratio of sulfur and accelerator. Mechanical properties of the vulcanizates were evaluated including hardness, tensile strength), elongation at break), tear resistance, rebound resilience), and compression set. The damping properties test was carried out at 100\% strain with four loops. The results finding showed that the conventional vulcanization system provided the highest hardness (30 Shore A), tear strength (13 N/ $\mathrm{mm})$, rebound resilience (24\%). The lowest compression set was also provided by the conventional vulcanization system. Meanwhile, the efficient vulcanization resulted in highest tensile strength (3 MPa) and elongation at break (960\%). The damping properties were represented by stiffness and shear modulus in which the highest value was given by the semi-efficient vulcanization system. They were $26.5049 \mathrm{~N} / \mathrm{mm}$ and $0.2120 \mathrm{MPa}$, respectively.
\end{abstract}

Keywords: butyl rubber, crosslink, damping, shear modulus, sulfur vulcanization.

\begin{abstract}
ABSTRAK
Sifat peredaman karet butil dipengaruhi banyaknya ikatan silang, jenis dan jumlah bahan pengisi yang digunakan. Pada penelitian ini karet butil dikompon tanpa menggunakan pengisi karena pengisi memberikan efek yang bervariasi terhadap sifat material yang dihasilkan. Kompon dibuat dengan sistem vulkanisasi belerang konvensional, semi efisien dan efisien dengan variasi perbandingan sulfur dan pencepat. Sifat mekanik -vulkanisat diuji kekerasan, kekuatan tarik, perpanjangan putus, ketahanan sobek, kepegasan pantul dan pampatan tetap. Pengujian mekanik sifat peredaman dilakukan pada regangan 100\% dengan loop empat kali. Hasil uji sistem vulkanisasi konvensional memberikan nilai tertinggi untuk kekerasan (30 shore A), kuat sobek (13 N/mm), kepegasan pantul (24\%), dan pampatan tetap (13\%). Sedangkan sistem vulkanisasi efisien memberikan nilai maksimum untuk kuat tarik (3 MPa), dan perpanjangan putus $(960 \%)$. Sifat peredaman diwakili oleh kekakuan dan modulus geser, dimana nilai tertinggi diberikan oleh sistem vulkanisasi semi-efisien. Nilai tertinggi secara berurutan yaitu $26,5049 \mathrm{~N} / \mathrm{mm}$ dan $0,2120 \mathrm{MPa}$.
\end{abstract}

Kata kunci: ikatan silang, karet butil, modulus geser, peredaman, vulkanisasi belerang.

\section{PENDAHULUAN}

Struktur bangunan merupakan komponen penting yang perlu diperhatikan dalam setiap perancangan suatu bangunan karena struktur ini berperan dalam menopang beban yang bersifat statis maupun dinamik. Beban statis dihasilkan dari beban bangunan tersebut sedangkan beban dinamik adalah beban bergerak yang nilainya dapat berubah serta dapat berlangsung terus menerus maupun sementara. Gempa bumi 
merupakan salah satu contoh beban dinamik yang dapat merusak struktur bangunan apabila struktur yang digunakan pada bangunan tidak tepat baik dimensi dan geometri sehingga getaran akan menjadi semakin besar karena resonansi dan mengakibatkan struktur tersebut rusak (Setio et al., 2012), dengan demikian menjaga kekuatan struktur bangunan sangat penting terutama apabila terjadi beban dinamis seperti gempa bumi.

Salah satu alternatif solusi untuk melindungi struktur bangunan adalah dengan memasang sistem isolator dasar yang terbuat dari karet. Karet bantalan tahan gempa (rubber seismic bearing) menjadi perangkat penting pada suatu struktur sebagai isolator dengan fungsi disipasi energi untuk mengurangi gaya seismik yang ditransmisikan dari tanah ke bangunan. Sistem isolator tersebut dipasang diantara pondasi dan struktur bangunan untuk meningkatkan deformabilitas struktur dan kemampuan redaman histeretik bangunan (Chung et al., 1999; Lei et al., 2019). Karet bantalan tahan gempa tersusun dari lapisan komposit karet yang saling dilekatkan secara berselang seling dengan pelat logam (Warn et al., 2007). Pemilihan jenis karet berpengaruh terhadap performa karet bantalan tahan gempa terutama dalam meredam getaran yang dihasilkan oleh gempa bumi. Karet yang memiliki sifat viskoselastis yang unik sangat ideal digunakan sebagai bahan peredam ( $\mathrm{Li}$ et al., 2006). Karet yang umum digunakan dalam pembuatan karet bantalan tahan gempa adalah karet alam dan karet butil.

Karet butil atau lebih dikenal dengan IIR merupakan salah satu tipe karet sintetik yang tersusun atas kopolimer linier dari monomer isoprena-isobutil dengan fraksi mol isoprena kurang dari 3\% (Vitiello et al., 2017). Penggunaan karet butil untuk produk peredam mempunyai peluang yang sangat baik terutama untuk tipe peredam Lead Rubber Bearings (LRB) dan High Damping Rubber Bearings (HDRB). Produk HDRB dibuat dari karet yang dicampur dengan bahan pemvulkanisasi, bahan pengisi seperti carbon black, bahan pelunak (Yuan et al., 2016). Bahan pengisi merupakan bahan paling banyak jumlahnya kedua setelah karet, sehingga sifat mekanik sebagian besar ditentukan oleh jumlah bahan pengisi yang ditambahkan.

Penelitian mengenai penggunaan variasi bahan pengisi carbon black dan silika dalam campuran kompon karet pernah dilakukan oleh $\mathrm{Fu}$ et al. (2016). Penelitian ini menggunakan carbon black dan silika dengan variasi 15, 30, 45, 60 berat perseratus karet (bsk) atau part perhundred rubber (phr) dengan pengujian sifat mekanik berupa uji kekerasan, kekuatan tarik, kuat sobek, perpanjangan putus, dan pantul. Hasil pengujian mekanik menunjukkan semakin banyak jumlah bahan pengisi carbon black dan silika yang ditambahkan maka nilai kekerasan, kuat sobek semakin naik, sedangkan kuat tarik dan perpanjangan putus dan pantul semakin menurun.

Sifat dinamik material diuji dengan menggunakan Dynamic Mechanical Analyzer (DMA). Pengujian menggunakan DMA bertujuan untuk melihat sifat peredaman dari suatu material yang merupakan fungsi waktu, tekanan atau kombinasi parameter tersebut (Hilmi \& Pratapa, 2016). Hasil penelitian Fu et al.(2016) uji dinamik berupa modulus simpan diperoleh hasil bahwa semakin banyakjumlah bahan pengisi carbon black yang ditambahkan menghasilkan nilai modulus simpan sangat besar hingga mencapai $3000 \mathrm{Kpa}$ yaitu pada $60 \mathrm{phr}$ carbon black, sedangkan nilai modulus simpan yang dicapai oleh bahan pengisi silika hanya mencapai dibawah $1000 \mathrm{Kpa}$ dengan nilai tertinggi dicapai pada $60 \mathrm{phr}$.

Penelitian penggunaan bahan pengisi seperti silika untuk melihat sifat redaman dari karet dilakukan oleh Shi et al. (2016) yang melakukan studi terhadap pengaruh bahan pengisi terhadap sifat peredaman ethylene vinyl acetate copolymer rubber (EVM). Penelitian ini menggunakan silika, mesoporous silika dan silika glass sebagai bahan pengisi. Hasil uji sifat mekanik seperti kuat tarik, perpanjangan putus, ketahanan sobek dan modulus menunjukkan hasil yang berbeda. Hasil uji peredaman pada penelitian tersebut terlihat bahwa penambahan silika pada karet EVM dapat memperbaikaki sifat peredaman terutama pada campuran silika dan mesoporous silika. Penggunaan bahan pengisi sangat mempengaruhi sifatperedaman, sehinggadiperlukan pertimbangan yang tepat dalam memilih jenis bahan pengisi karena hasil sifat mekanik dan dinamik dari setiap jenis bahan pengisi adalah berbeda.

Selain faktor bahan pengisi, faktor pemilihan sistem vulkanisasi juga sangat penting. Sistem vulkanisasi juga mempengaruhi sifat mekanik karet karena dalam karet yang sudah tervulkanisasi terdapat ikatan silang dalam matrik karet. Ketiga sistem vulkanisasi belerang yaitu sistem vulkanisasi konvensional, vulkanisasi semi efisien dan vulkanisasi efisien dimana masing-masing 
Tabel 1. Formula kompon karet butil.

\begin{tabular}{clcccccc}
\hline \multirow{2}{*}{ No } & \multirow{2}{*}{ Bahan } & \multicolumn{7}{c}{ Komposisi (phr) } \\
\cline { 3 - 7 } & Karet butil & $\mathrm{G}$ & $\mathrm{H}$ & $\mathrm{I}$ & $\mathrm{J}$ & $\mathrm{K}$ & $\mathrm{L}$ \\
\hline 1 & 100 & 100 & 100 & 100 & 100 & 100 \\
2 & ZnO & 5 & 5 & 5 & 5 & 5 & 5 \\
3 & Asam stearat & 2 & 2 & 2 & 2 & 2 & 2 \\
4 & CBS & 1,4 & 1,4 & 1,4 & 1,4 & 1,4 & 1,4 \\
5 & Belerang & 0,25 & 0,35 & 1,4 & 1,7 & 3,0 & 3,5 \\
\hline
\end{tabular}

mempunyai perbedaan terutama perbandingan jumlah belerang dan bahan pencepat. Sistem konvensional penggunaan belerang lebih banyak dari bahan pencepat, sistem efisien penggunaan belerang lebih sedikit dari bahan pencepat dan sistem semi efisien penggunaan belerang dan bahan pencepat sama.

Sistem konvensional menghasilkan ikatan silang dalam jumlah banyak karena belarang yang digunakan banyak, sehingga ikatan silang yang terbentuk jenis polisulfida. Ikatan silang yang terbentuk dalam jumlah yang banyak dalam matrik karet mengakibatkan karet cenderung lebih kaku dikarenakan dalam matrik karet ruang kosong sudah terpenuhi dengan ikatan silang yang mengakibatkan rantai polimer semakin sulit bergerak dan kaku (Thiranan, 2007). Akibat dari semakin kaku material karet maka akan berpengaruh terhadap sifat peredaman karet.

Penelitian ini melakukan studi mengenai pengaruh variasi sistem vulkanisasi konvensional, vulkanisasi semi efisien dan vulkanisasi efisien pada vulkanisat karet butil terhadap sifat fisik dan mekanik berupa sifat peredaman. Pada penelitian tidak ditambahkan bahan pengisi karena pengaruh bahan pengisi terhadap sifat material sangat bervariasi hal ini dikarenakan jenis, ukuran bahan pengisi sangat beragam yang tersedia di pasaran sehingga analisa lebih pada pengaruh sistem vulkanisasi yang digunakan.

Tabel 2. Proses pembuatan kompon.

\begin{tabular}{clc}
\hline No & Proses & Waktu (menit) \\
\hline 1 & Mastikasi karet & 3 \\
2 & ZnO & 2 \\
3 & Asam stearat & 2 \\
4 & CBS & 2 \\
5 & Belerang & 1 \\
6 & Remiling & 1 \\
7 & Reblending & 1 \\
\hline
\end{tabular}

\section{BAHAN DAN METODE Bahan Penelitian}

Penelitian menggunakan bahan yang diperlukan dalam pembuatan kompon karet terdiri atas karet butil merek CB 1240 dari Lanxess Jerman sebagai base elastomer, bahan pengaktif berupa zinc oxide ( $\mathrm{ZnO}) \mathrm{UN} 3077$ dari Lanxess Jerman, asam stearat Aflux ${ }^{\circledR 52}$ dari Lanxess Jerman, bahan pencepat berupa $\mathrm{N}$-Cyclohexyl-2benzothiazole Sulfenamide (CBS) merek Kemai China, dan bahan pemvulkanisasi berupa belerang (sulfur) merek Midas SP 325 produksi Miwon Co Jepang. Bahan kimia kompon karet yang digunakan seluruhnya pada tingkatan mutu teknis. Formula kompon karet yang diaplikasikan dalam eksperimen ini dirancang pada berbagai variasi dosis belerang seperti pada Tabel 1 .

\section{Metode Penelitian \\ Pembuatan kompon}

Eksperimen dimulai dengan pencamburan karet dengan bahan kimia dalam mesin giling terbuka skala laboratorium berkapasitas 1000 $\mathrm{g} /$ batch merek Berstorf buatan Jerman untuk menghasilkan campuran berupa kompon karet. Pada pembuatan kompon ini mengacu pada standar ASTM 3182 yang terdiri dari tahapan pada Tabel 2.

Karet butil dimastikasi hingga viskositas turun sehingga lebih mudah bercampur dengan bahan kimia. Karet butil yang telah dimastikasi menjadi lebih lunak ditandai dengan wujudnya yang menjadi plastis. Selanjutnya bahan kimia kompon karet ditambahkan dalam karet butil dengan urutan $\mathrm{ZnO}$, asam stearat, $\mathrm{CBS}$ dan terakhir belerang. Setelah seluruh bahan kimia kompon karet selesai ditambahkan, maka karet terus digiling dan dihomogenkan (remilling and blending). Pada kompon karet butil yang telah dihomogen kemudian dicuplik sekitar $50 \mathrm{~g}$ sebagai sampel uji karakteristik vulkanisasi. Sementara 


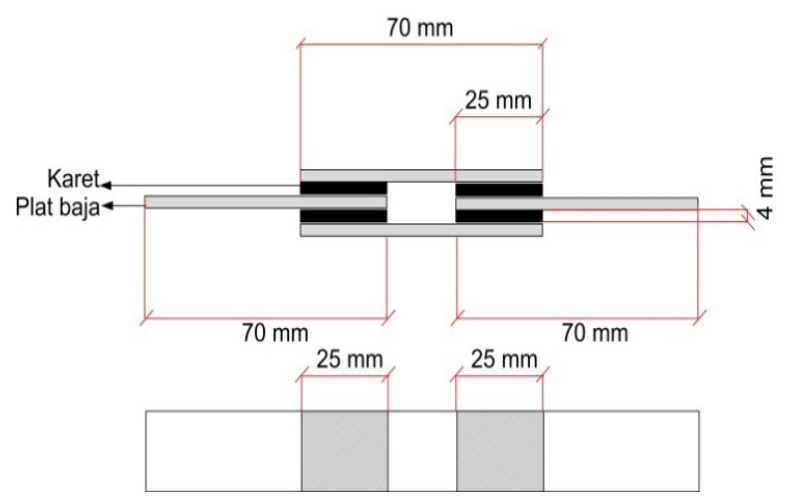

Gambar 1. Sampel uji sifat redaman.

sisa kompon karet butil dicetak sebagai sampel uji sifat fisik dan mekanik.

\section{Pengujian karakteristik vulkanisasi}

Pengujian karakteristik vulkanisasi dilakukan sesuai prosedur uji pada ASTM D2084-17 (ASTM, 2017) pada suhu $170{ }^{\circ} \mathrm{C}$ menggunakan Rheometer tipe disk merek Alpha 2000 buatan Amerika. Pada pengujian ini diperoleh waktu vulkanisasi optimal $\left(t_{90}\right)$ yang selanjutnya digunakan dalam proses pencetakan kompon menjadi vulkanisat. Proses pencetakan dilakukan pada mesin tekan hidrolik merek KMC buatan Jepang.

\section{Pengujian sifat fisis dan mekanis}

Pengujian sifat fisis dan mekanis meliputi parameter kekerasan dengan menggunakan alat uji kekerasan Shore A merek Frank Durometer buatan Jerman sesuai dengan standar ASTM D2240 (ASTM, 2015). Pengujian kuat tarik dilakukan dengan menggunakan Universal Testing Machine (UTM) yaitu mesin uji tarik merek MTS buatan Amerika sesuai standar ASTM D412-16 (ASTM, 2016), sementara untuk perpanjangan putus mengacu pada SNI ISO 37:2015 (BSN, 2015). Pengujian ketahanan sobek menggunakan mesin UTM Instron standar ASTM D624-00 (ASTM, 2012) buatan Kanada, uji kepegasan pantul dengan Tripsometer ASTM D1054-02 (ASTM, 2007), dan uji pampatan tetap E-Set Tester sesuai ASTM D395 (ASTM, 2016) dengan pengujian dilakukan pada suhu ruang selama $3 \times 24$ jam.

\section{Pengujian sifat peredaman}

Pengujian sifat redaman dilakukan pada kondisi suhu ruang $23-25^{\circ} \mathrm{C}$. dengan sampel dalam bentuk vulkanisat karet yang dipadukan dengan plat logam seperti yang disajikan pada Gambar

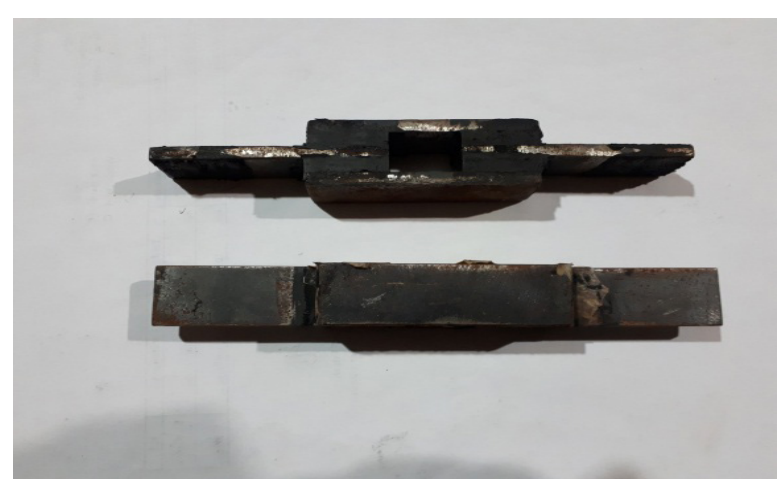

1. Pengujian dilakukan dengan 4 kali siklus penarikan kearah positif dengan $100 \%$ regangan. Alat yang digunakan adalah menggunakan mesin UTM merek MTS dengan pengujian sesuai EN 15129:2018 (CEN, 2018).

Hasil yang diperoleh adalah berupa kurva hubungan displacement $(\mathrm{mm})$ vs tenaga tarik $(\mathrm{N})$ bentuk loop. Hasil data yang diperoleh kemudian dilakukan perhitungan menggunakan persamaan (1), (2), dan (3) untuk mendapatkan kekakuan geser, damping rasio, dan modulus geser efektif (Koupai et al., 2017).

$K_{H}=\frac{Q_{1}-Q_{2}}{X_{1}-X_{2}}$

$h_{e q}=\frac{2 \Delta W}{\pi K_{h}\left(X_{1}-X_{2}\right)^{2}}$

$G=\frac{K_{H} t_{r}}{A_{r}}$

dimana, $\mathrm{K}_{\mathrm{H}}$ adalah kekakuan geser, $\mathrm{h}_{\mathrm{eq}}$ adalah rasio damping ekuivalen, $\mathrm{Q}_{1}$ adalah gaya geser maksimum, $\mathrm{Q}_{2}$ adalah gaya geser minimum, $\mathrm{X}_{1}$ adalah perpanjangan maksimum, $\mathrm{X}_{2}$ adalah perpanjangan minimum pada siklus ketiga. $\Delta \mathrm{W}$ adalah luas area pada dibawah kurva histerisis loop ketiga, serta $A_{r}$ dan $t_{r}$ merupakan luas area karet dan tebal karet.

\section{HASIL DAN PEMBAHASAN \\ Karakteristik Vulkanisasi}

Data hasil pengujian karakteristik vulkanisasi disajikan dalam Tabel 3. Pengujian ini untuk mengetahui waktu vulkanisasi optimum $\left(\mathrm{tc}_{90}\right)$ atau waktu matang (curing time). Data lain adalah berupa torsi maksimum (MH) dan torsi minimum (ML) dan waktu pravulkanisasi ( $\mathrm{ts}_{2}$ ).

Hasil yang diperoleh untuk karakteristik vulkanisasi menunjukkan bahwa semakin banyak 


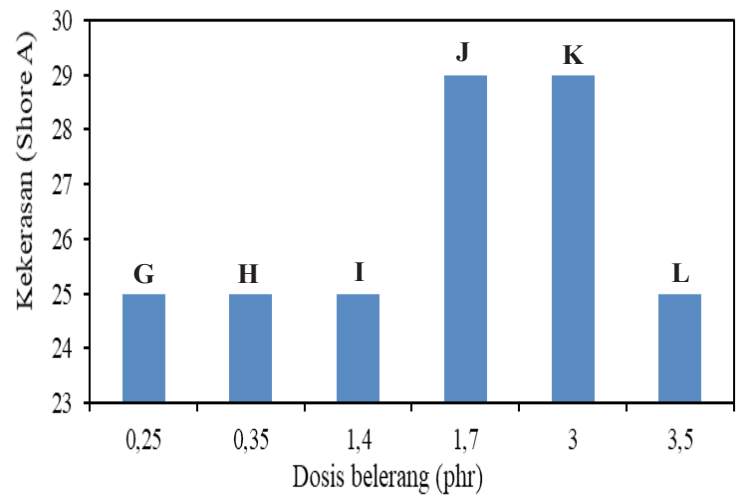

Gambar 2. Kekerasan vulkanisat karet butil.

belerang yang ditambahkan mengakibatkan proses pematangan $\mathrm{tc}_{90}$ (curing time) lebih panjang hingga 18 menit. Vulkanisasi karet dengan menggunakan belerang merupakan proses yang berjalan lambat hingga beberapa jam dan umumnya dilakukan pada temperatur $140{ }^{\circ} \mathrm{C}$ atau lebih (Tamási \& Kollár, 2018). Sistem konvensional pada kompon $\mathrm{K}$ dan $\mathrm{L}$ mengandung jumlah belerang yang banyak dengan sedikit pencepat sehingga proses terbentuknya ikatan silang memerlukan waktu lama, sedangkan pada kompon efisien $(\mathrm{G}, \mathrm{H})$ lebih banyak mengandung pencepat sehingga waktu curing time $\left(\mathrm{tc}_{90}\right)$ lebih pendek. Namun demikian penggunaan bahan pencepat dalam jumlah besar dapat mengakibatkan lewat matang (over curing) pada vulkanisat yang berakibat terjadi degradasi pada vulkanisat sesudah terbentuk ikatan silang dalam matrik karet sehingga mengakibatkan sifat mekaniknya turun (Reshmy et al., 2012). Pencampuran yang dinilai efektif adalah jumlah bahan pencepat lebih sedikit dan jumlah belerang juga sedikit tetapi sifat mekanik vulkanisat yang dicapai optimal (Kruželák et al., 2016).

Susunan formulasi dan karakteristik kompon serta vulkanisat tanpa bahan pengisi dari Tabel 2 dapat terlihat bahwa dengan bertambahnya dosis sulfur dalam formulasi karet butil menyebabkan

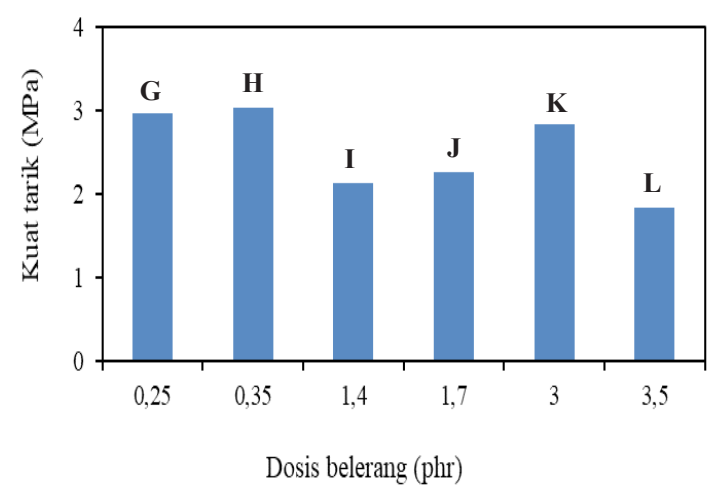

Gambar 3. Kuat tarik vulkanisat karet butil.

bertambahnya nilai modulus torsi maksimal (MH) maupun minimal (ML) serta selisih modulus torsi (MH-ML). Nilai MH menggambarkan kekakuan dari vulkanisat karet, semakin besar nilai $\mathrm{MH}$ maka semakin kaku kompon tersebut. Sementara nilai ML berkaitan dengan kemampuan proses dari kompon karet, semakin rendah nilai ML maka semakin mudah kompon tersebut diproses. Selanjutnya nilai MH-ML mengindikasikan jumlah ikatan silang antara molekul karet dengan sulfur yang terbentuk pada saat reaksi vulkanisasi. Selanjutnya waktu vulkanisasi optimal $\left(\mathrm{tc}_{90}\right)$ mengilustrasikan waktu yang diperlukan oleh kompon karet untuk mencapai 90\% kondisi vulkanisasi (Ngamsurat et al., 2011).

\section{Sifat Fisis Vulkanisat}

Nilai kekerasan didefinisikan sebagai ketahanan material terhadap beban permanen yang dalam hal ini digunakan indentasi atau penekanan. Nilai kekerasan pada material karet dipengaruhi oleh adanya ikatan silang dan bahan pengisi yang digunakan (Hidayat et al., 2019). Nilai kekerasan cenderung masih dapat meningkat seiring dengan lamanya waktu vulkanisasi atau pun dengan kenaikan temperatur (Saputra et al., 2020). Pada penelitian ini tidak menggunakan bahan pengisi

Tabel 3. Karakteristik vulkanisasi kompon karet butil.

\begin{tabular}{cccccccc}
\hline \multirow{2}{*}{ No } & \multirow{2}{*}{ Parameter } & 0,25 & 0,35 & 1,4 & 1,7 & 3,0 & 3,5 \\
\cline { 3 - 7 } & \multirow{2}{*}{ MH, dNm } & 3,18 & 3,19 & 3,99 & 5,39 & 4,73 & 5,95 \\
\hline 1 & ML, dNm & 2,12 & 1,15 & 0,01 & 0,81 & 0,64 & 0,77 \\
3 & MH - ML, dNm & 1,06 & 2,04 & 3,98 & 4,58 & 4,09 & 5,18 \\
4 & ts $_{2}$, menit:detik & 15,05 & 18,14 & 7,26 & 6,16 & 7,02 & 5,56 \\
5 & tc $_{90}$, menit:detik & 13,47 & 14,56 & 15,52 & 18,05 & 18,09 & 18,35 \\
\hline
\end{tabular}




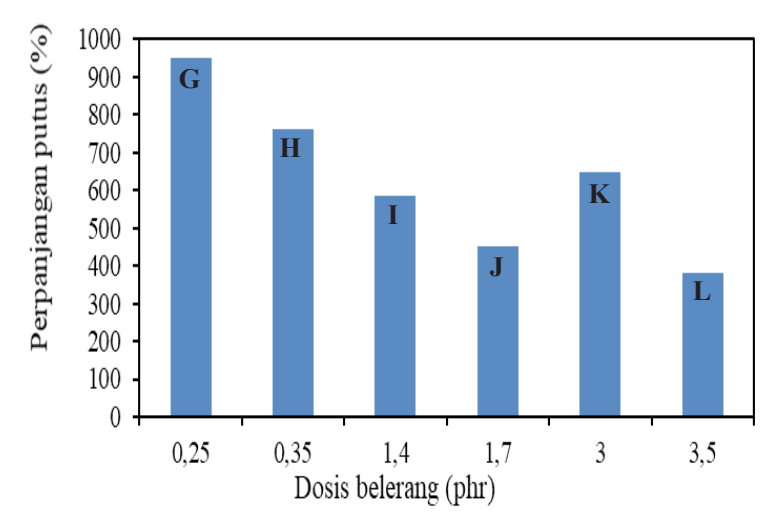

Gambar 4. Perpanjangan putus vulkanisat karet butyl.

dan suhu vulkanisasi adalah sama $170{ }^{\circ} \mathrm{C}$ sehingga pengaruh kekerasan banyak dipengaruhi pada jumlah ikatan silang yang terbentuk. Hasil uji nilai kekerasan disajikan pada Gambar 2.

Pengujian nilai kuat tarik menghasilkan nilai yang bervariasi. Terlihat pada Gambar 3. diperoleh nilai kuat tarik tertinggi pada kompon $\mathrm{G}$ dan $\mathrm{H}$. Kompon $\mathrm{G}$ menggunakan jumlah belerang yang sedikit sehingga terbentuknya ikatan silang lebih maksimal, sedangkan pada kompon L dengan belerang banyak dan waktu vulkanisasi tak jauh berbeda dengan kompon $G$ nilai kuat tariknya rendah dikarenakan jumlah ikatan silang yang terbentuk belum maksimal.

Sejalan dengan nilai kuat tarik untuk nilai perpanjangan putus pada Gambar 4 diperoleh hasil yang fluktuatif dengan semakin bertambahnya belerang. Pada Gambar 4 trend menurun terjadi pada penambahan belerang pada masing masing sistem vulkanisasi.

Sifat ketahanan sobek sangat berkorelasi

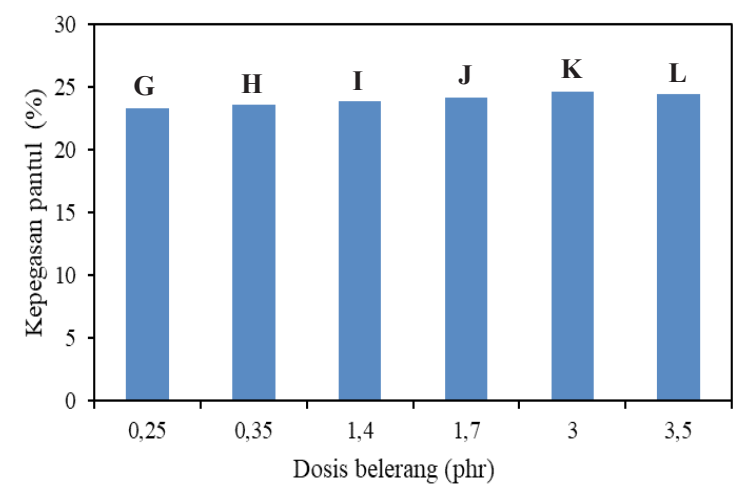

Gambar 6. Kepegasan pantul vulkanisat karet butyl.

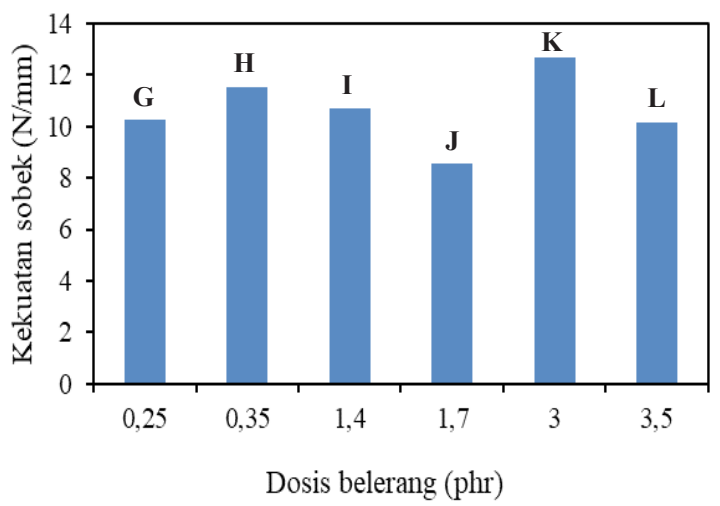

Gambar 5. Kekuatan sobek vulkanisat karet butil.

dengan sifat tarik vulkanisat karet. Nilai ketahanan sobek ditentukan oleh bentuk potongan uji, kecepatan tarik dan suhu pengujian. Arah gilingan karet juga bisa berpengaruh pada vulkanisat karet. Oleh karena berkorelasi dengan nilai kuat tarik pada nilai kekuatan sobek ditentukan dari ikatan silang yang terbentuk pada vulkanisat. Pada Gambar 5 kompon $\mathrm{K}$ menghasilkan nilai kuat sobek paling tinggi dibanding dengan kompon lainnya, karena vulkanisasi konvensional pada kompon $\mathrm{K}$ dan $\mathrm{L}$ menjadikan karet mempunyai ikatan silang yang sangat kuat apabila dikenai gaya tarik dengan potongan sobek pada sisi yang ditentukan.

Nilai kepegasan pantul merupakan ukuran dari kemampuan material dalam menerima atau menyerap energi yang dihasilkan karena gaya atau benturan yang terjadi dengan cepat. Akibat aksi benturan ini material dapat berubah bentuk atau mampu mempertahankan bentuk untuk kembali ke bentuk awal. Kepegasan pantul ketika terjadi deformasi merupakan perbandingan energi

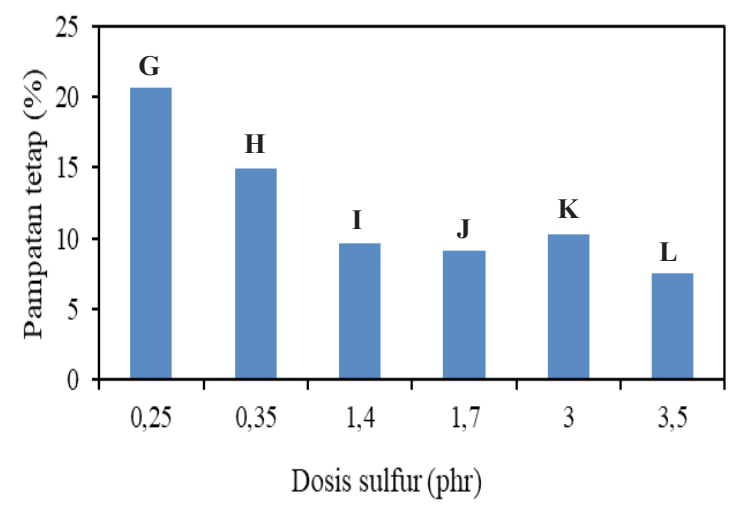

Gambar 7. Pampatan tetap vulkanisat karet butil. 
sesudah dan sebelum benturan yang dinilai dalam bentuk persentase (Wadha, 2012). Nilai kepegasan pantul untuk keenam kompon pada Gambar 6 ini tidak berbeda jauh meskipun cenderung meningkat dengan bertambahnya belerang pada kompon. Kepegasan pantul yang rendah berarti vulkanisat tersebut mempunyai sifat peredaman yang baik.

Pada uji pampatan tetap (Gambar 7) terlihat semakin banyak belerang nilai pampatan tetap menurun. Nilai pampatan tetap cenderung dipengaruhi oleh sifat elastis dari material karena kemampuan material untuk kembali ke bentuk semula setelah melalui proses pembebanan selama waktu yang ditentukan. Dari hasil terlihat kompon $\mathrm{G}$ persentase perubahan kompressi besar karena jumlah belerang sedikit sehingga ikatan silang yang terbentuk sedikit, sedangkan pada kompon $L$ nilai perubahan pampatan tetap persentasenya lebih kecil karena pada kompon L belerang yang digunakan lebih banyak sehingga terbentuk ikatan silang cenderung lebih banyak dari kompon L.

\section{Uji Sifat Peredaman}

Hasil uji sifat peredaman disajikan dalam Tabel 3 yang menyajikan data kekakuan geser $\mathrm{K}_{\mathrm{H}}$, tegangan geser $\left(\mathrm{N} / \mathrm{mm}^{2}\right)$, regangan geser $(\%)$, modulus geser (MPa) dan histerisis (\%).Kompon I, J dan K menghasilkan nilai kekakuan geser yang tinggi dari pada kompon lainnya. Nilai kekakuan ini merupakan tahanan terhadap adanya gaya geser sehingga material tidak terjadi deformasi. Semakin lama gaya geser yang diterima kekakuan ini akan meningkat karena pengaruh hardening effect, sehingga pengaruh ini berfungsi sebagai batasan sebelum terjadi deformasi yang melebihi batas (Budiono \& Setiawan, 2014). Pada kompon K dan $\mathrm{L}$ merupakan kompon dengan sistem vulkanisasi konvensional, sehingga mempunyai ikatan silang jenis polisulfida $(\mathrm{C}-\mathrm{Sx}-\mathrm{C})$. Ikatan jenis polisulfida merupakan ikatan yang kuat dibanding dengan ikatan belerang dengan belerang seperti ikatan di- sulfidia (C-S-S-C) (Koupai et al., 2017).

Kemampuan mempertahanankan bentuk juga merupakan faktor penting dalam mendesain material untuk peruntukan produk peredam (isolation bearing), terutama pada peredam yang mengalami aksi geser. Karet yang mengalami strain-induced crystallization ketika mengalami deformasi sehingga kemampuan karet ini meningkatkan sifat elastisitas dan ketahanan terhadap kerusakan, oleh karena itu sifat-sifat ini berperan penting agar karet dapat memenuhi persyaratan sebagai isolation bearing (Wang et al., 2016). Pada nilai modulus geser kompon I, J dan K tidak terlalu berbeda jauh. Nilai modulus geser dihasilkan berdasarkan perbandingan antara tegangan geser dan regangan geser. Nilai modulus geser yang besar artinya tegangan gesernya besar dan regangan kecil sehingga dapat dianalogi sebagai kekakuan material terhadap gaya geser. Nilai modulus geser yang dihasilkan masih dibawah 0,4 MPa, sehingga masih dikategorikan material soft karena material yang digunakan tidak menggunakan bahan pengisi.

Sifat peredaman yang baik pada kompon karet butil dikarenakan keberadaan gugus metil pada rantai molekul karet butil menyebabkan karet butil memiliki sifat redaman yang baik (Li et al., 2019). Lebih lanjut, menurut Xia et al (2018), karet butil dikenal dengan kemampuan disipasi energinya yang tinggi dibandingkan dengan polimer yang lain, sehingga karet butil memiliki kisaran suhu operasi redaman yang luas. Karet butil yang telah mengalami vulkanisasi terbentuk ikatan silang antar rantai polimer karet oleh atom-atom belerang sehingga mengakibatkan perubahan pada struktur molekul polimer karet. Ikatan silang dapat membuat molekul polimer karet sulit bergerak secara bebas sehingga menjadi kaku dan sifat elastisnya meningkat (Novianti et al., 2015).

Tabel 4. Hasil uji sifat peredaman.

\begin{tabular}{cccccc}
\hline Kompon & $\begin{array}{c}\text { Kekakuan geser, } \\
\mathrm{K}_{\mathrm{H}}(\mathrm{N} / \mathrm{mm})\end{array}$ & $\begin{array}{c}\text { Tegangan geser } \\
\left(\mathrm{N} / \mathrm{mm}^{2}\right)\end{array}$ & $\begin{array}{c}\text { Regangan } \\
\text { geser }(\%)\end{array}$ & $\begin{array}{c}\text { Modulus geser, } \\
\mathrm{G}(\mathrm{MPa})\end{array}$ & $\begin{array}{c}\text { Histerisis, } \mathrm{H} \\
(\%)\end{array}$ \\
\hline $\mathrm{G}$ & 24,5276 & 0,1936 & 0,986 & 0,1962 & 4,75 \\
$\mathrm{H}$ & 25,7147 & 0,2066 & 1,004 & 0,2057 & 4,74 \\
$\mathrm{I}$ & 26,5049 & 0,2129 & 1,004 & 0,2120 & 3,10 \\
$\mathrm{~J}$ & 26,4819 & 0,2128 & 1,004 & 0,2118 & 2,84 \\
$\mathrm{~K}$ & 24,5097 & 0,1969 & 1,004 & 0,1960 & 3,52 \\
$\mathrm{~L}$ & 26,3315 & 0,2115 & 1,004 & 0,2106 & 3,32 \\
\hline
\end{tabular}




\section{KESIMPULAN}

Penggunaan sistem vulkanisasi konvensional, vulkanisasi semi efisien dan vulkanisasi efisien pada kompon karet butil menghasilkan sifat fisik dan mekanik yang berbeda. Berdasarkan uji sifat mekanik sistem vulkanisasi konvensional mempunyai kekuatan tarik lebih tinggi demikian juga pada ketahanan terhadap deformasi akibat tekanan. Sistem vulkanisasi konvensional mengandung lebih banyak belerang sehingga dapat menghasilkan ikatan silang lebih banyak sehingga dapat meningkatkan kekuatan mekanik vulkanisat. Sifat dinamik vulkanisat dengan sistem konvensional dan semi efisien lebih baik dikarenakan pengaruh adanya ikatan silang yang menahan pergerakan kearah horizontal dari vulkanisat yang menyebabkan nilai modulus gesernya besar. Pemilihan sistem vulkanisasi dalam sebuah perancangan produk peredam sangat penting karena berhubungan dengan sifat mekanik dan dinamik vulkanisat produk vulkanisat karet khususnya untuk produk peredam.

\section{UCAPAN TERIMA KASIH}

Seluruh Penulis mengucapkan terima kasih dan memberikan penghargaan tinggi kepada Kementerian Riset dan Teknologi/BRIN dan Lembaga Pengelola Dana Pendidikan (LPDP) atas bantuan dana riset melalui Program Rispro Mandatori Program Prioritas Riset Nasional (PRN) Tahun 2020 (Kontrak Perjanjian Nomor 152/E1/PRN/2020). Ucapan terima kasih turut disampaikan pula kepada para Teknisi Pabrik Percobaan dan Analisis Laboratorium Pengujian Balai Penelitian Teknologi Karet Pusat Penelitian Karet atas konstribusi selama pelaksanaan kegiatan penelitian.

\section{DAFTAR PUSTAKA}

ASTM (American Society for Testing and Materials). (2007). ASTM D1054-02 Test method for rubber property - Resilience using a Goodyear - Healey rebound pendulum. Pennsylvania, USA: ASTM.

ASTM (American Society for Testing and Materials). (2012). ASTM D624-00 Standard test method for tear strength of conventional vulcanized rubber and thermoplastic elastomers. Pennsylvania, USA: ASTM.

ASTM (American Society for Testing and Materials). (2015). ASTM D2240-15 Standard test method for rubber property - Durometer hardness. Pennsylvania, USA: ASTM.

ASTM (American Society for Testing and Materials).
(2016). ASTM D395 Standard test methods for rubber property - Compression set. Pennsylvania, USA: ASTM.

ASTM (American Society for Testing and Materials). (2016). ASTM D412-16 Standard test methods for vulcanized rubber and thermoplastic elastomers Tension. Pennsylvania, USA: ASTM.

ASTM (American Society for Testing and Materials). (2017). ASTM D2084-17 Standard test method for rubber property - Vulcanization using oscillating disk cure meter. Pennsylvania, USA: ASTM.

BSN (Badan Standardisasi Nasional). (2015). SNI ISO 37:2015 Karet, vulkanisat atau termoplastik Penentuan sifat-sifat tegangan-regangan (ISO 37:2011, IDT). Jakarta, Indonesia: BSN.

Budiono, B., \& Setiawan, A. (2014). Studi komparasi sistem isolasi dasar high-damping rubber bearing dan friction pendulum system pada bangunan beton bertulang. Jurnal Teknik Sipil, 21(3), 179196. https://doi.org/10.5614/jts.2014.21.3.1

CEN (European Committee for Standardization). (2018). EN 15129:2018 Anti-seismic devices. Brussels, Belgia: CEN.

Chung, W. J., Yun, C. B., Kim, N. S., \& Seo, J. W. (1999). Shaking table and pseudodynamic tests for the evaluation of the seismic performance of base-isolated structure. Engineering Structure, 21(4), 365-379. https://doi.org/10.1016/S0141$\underline{0296(97) 00211-3}$

Fu, G., Chang, X., Mao, J., \& Shi, X. (2016). Insights into the reinforcement of butyl rubber by carbon black and silica with the aid of their dynamic properties. Journal of Macromolecular Science, 55(9), 925-936. https://doi.org/10.1080/0022234 8.2016 .1217760

Hidayat, A. S., Arti, D. K., Wisojodharmo, L. A., Harahap, M. E., \& Susanto, H. (2019). Effect of peptizer in mastication process of natural rubber/ butadiene rubber blending: Rheological and mechanical properties. International Journal of Engineering \& Scientific Research, 7(7), 16-22.

Hilmi, A. R., \& Pratapa, S. (2016). Sifat termomekanik komposit $\mathrm{PEG} / \mathrm{SiO} 2$ amorf menggunakan Dynamic Mechanical Analyzer (DMA). Jurnal Sains dan Seni ITS, 5(2), B-125-128.

Koupai, S. A., Bakhshi, A., \& Tabrizi, V. V. (2017). Experimental investigation on effects of elastomer components on dynamic and mechanical properties in seismic isolator compounds. Construction and Building Materials, 135, 267-278. https://doi. org/10.1016/i.conbuildmat.2016.12.184

Kruželák, J., Sýkora, R., \& Hudec, I. (2016). Sulphur and peroxide vulcanisation of rubber compounds - overview. Chemical Papers, 70, 1533-1555. https://doi.org/10.1515/chempap-2016-0093

Lei, T., Zhang, Y.-W., Kuang, D.-L., \& Yang, Y.-R. (2019). Preparation and properties of rubber 
blends for high damping isolation bearing. Polymers, 11(8), 1374. https://doi.org/10.3390/ polym 11081374

Li, C., Xu, S.-A., Xiao, F.-Y., \& Wu, C.-F. (2006). Dynamic mechanical properties of chlorinated butyl rubber blends. European Polymer Journal, 42(10), 2507-2514. https://doi.org/10.1016/j. eurpolymj.2006.06.004

Li, J.-C., Zhang, H.-S., Zhao, X.-Y., Jiang, J.-G., Wu, Y.-X., Lu, Y.-L., Zhang, L,-Q, \& Nishi, T. (2019). Development of high damping natural rubber/butyl rubber composite compatibilized by isobutyleneisoprene block copolymer for isolation bearing. Express Polymer Letters, 13(8), 686-696. https:// doi.org/10.3144/expresspolymlett.2019.58

Ngamsurat, S., Boonkerd, K., Leela-adisorn, U., \& Potiyaraj, P. (2011). Curing characteristic of natural rubber filled with gypsum. Energy Procedia, 9, 452-458. https://doi.org/10.1016/j. egypro.2011.09.051

Novianti, Widhiyanti, S., \& Sukamdo, P. (2015). Pembuatan benda uji base-isolation untuk rumah sederhana tahan gempa. Rekayasa Sipil, 4(2), 97-107.

Reshmy, R., Thomas, K. K., \& Sulekha, A. (2012). N-benzoyl-N'N'-disubstituted thioureas - A new binary accelerator system and its effect of nucleophilicity in sulfur vulcanization of natural rubber. Journal of Applied Polymer Science, 124(2), 978-984. $\quad$ https://doi.org/10.1002/ app. 35144

Saputra, D. A., Husin, S., Gumelar, M. D., Aisiah, N., Susanto, H., Admi, R. I., \& Anindita, G. L. (2020). Preparation and characterization of hard rubber and soft rubber for marine rubber fender. Macromolecular Symposia, 391(1), 1900189. https://doi.org/10.1002/masy.201900189

Setio, H. D., Kusumastuti, D., Setio, S., Siregar, P. H. R., \& Hartanto, A. (2012). Pengembangan sistem isolasi seismikpadastrukturbangunanyang dikenai beban gempa sebagai solusi untuk membatasi respon struktur. Jurnal Teknik Sipil, 19(1), 1-14. https://doi.org/10.5614/jts.2012.19.1.1

Shi, X., Jia, L., Ma, Y., \& Li, C. (2016). Effect of fillers on the damping properties of ethylene vinyl- acetate/polylactic acid blend. Journal of Materials Science and Chemical Engineering, 4(2), 89-96. https://doi.org/10.4236/msce.2016.42010

Tamási, K., \& Kollár, M. S. (2018). Effect of different sulfur content in natural rubber mixtures on their thermo-mechanical and surface properties. International Journal of Engineering Research \& Science, 4(2), 28-37. https://doi.org/10.5281/ zenodo. 1187676

Thiranan, T. (2007). Utilization of various filler for rubber mat development (Tesis). Kasetsart University, Thailand.

Vitiello, R., Tesser, R., Turco, R., Santacesaria, E., Compagnone, G., \& Di Serio, M. (2017). A critical review on analytical methods and characterization of butyl and bromobutyl rubber. International Journal of Polymer Analysis and Characterization, 22(4), 348-360. https://doi.org/ 10.1080/1023666X.2017.1297887

Wadha, A. (2012). Measuring the rebound resilience of a bouncing ball. Physics Education, 47(5), 620 626. https://doi.org/10.1088/0031-9120/47/5/620

Wang, W., Zhao, D., Yang, J., Nishi, T., Ito, K., Zhao, X., \& Zhang, L. (2016). Novel slide-ring material/ natural rubber composites with high damping property. Scientific Report, 6, 22810. https://doi. org $/ 10.1038 /$ srep 22810

Warn, G. P., Whittaker, A. S., \& Constantinou, M. C. (2007). Vertical stiffness of elastomeric and lead-rubber seismic isolation bearings. Journal of Structural Engineering, 133(9), 12271236. https://doi.org/10.1061/(ASCE)07339445(2007)133:9(1227)

Xia, L., Li, C., Zhang, X., Wang, J., Wu, H., \& Guo, S. (2018). Effect of chain length of polyisobutylene oligomers on the molecular motion modes of butyl rubber: Damping property. Polymer, 141, 70-78. https://doi.org/10.1016/j.polymer.2018.03.009

Yuan, Y., Wei, W., Tan, P., Iragashi, A., Zhu, H., Iemura, H., \& Aoki, T. (2016). A rate-dependent constitutive model of high damping rubber bearings: Modeling and experimental verification. Earthquake Engineering \& Structural Dynamics, 45(11), 1875-1892. https://doi.org/10.1002/ eqe. 2744 
